\title{
Tectonic Plates Come Apart at the Seams
}

\section{The scars of ancient collisions are the very places where continents rip again}

\section{J. Brendan Murphy, Gabriel Gutiérrez-Alonso, R. Damian Nance, Javier Fernández-Suárez, J. Duncan Keppie, Cecilio Quesada, Rob A. Strachan and Jaroslav Dostal}

\begin{abstract}
round the time that the first birds A evolved from their reptilian ancestors, between 100 million and 200 million years ago, the Atlantic Ocean was being born. Its creation marked the destruction of the supercontinent Pangea,
\end{abstract}

in which all the land on Earth formed a gigantic, unbroken island surrounded by a worldwide sea. But Pangea isn't the only supercontinent-just the most recent one. The landmasses we see today have cruised around the globe, smash- ing together and splitting apart several times over the past 3 billion years. These cycles of amalgamation and dispersal have affected the Earth's crust and underlying mantle, its atmosphere and climate, and the life it supports.

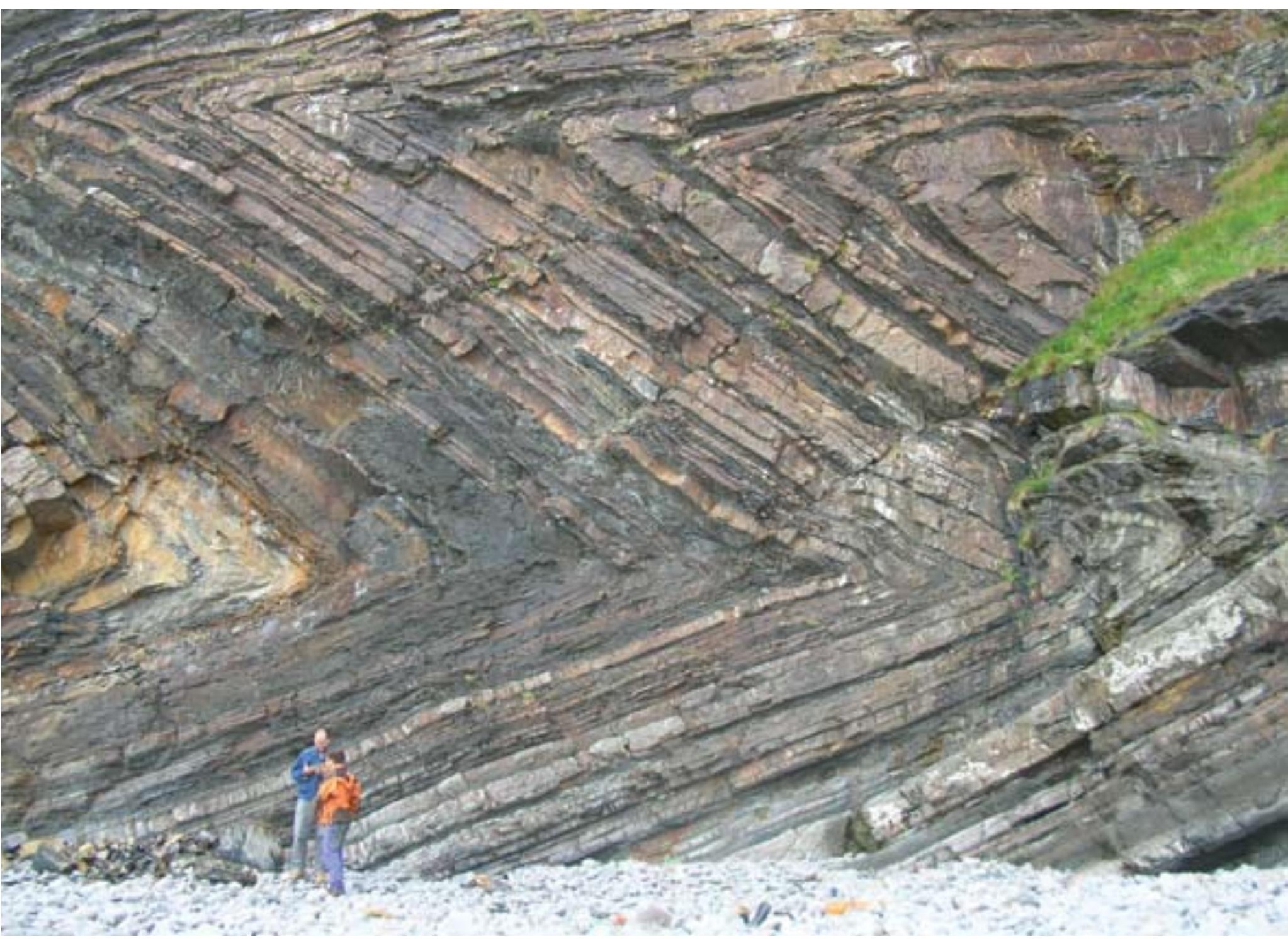

Figure 1. The collision of tectonic plates produces enough heat to deform continents. This outcropping on the Cornwall coast in southwestern England shows evidence of having been folded by the heat and pressure associated with plate collisions. (Photograph courtesy of the authors.) 
Just as continental collisions form mountains, continental separations form rifts, or ocean basins. Not all oceans, however, are created by the splitting apart of large continental blocks. Some are created when long, narrow "microcontinents" (about the size of New Zealand or Japan) split off from the edge of a continental block and drift away, creating a new ocean basin behind them. Stephen Johnston at the University of Victoria in Canada calls these slender titans "ribbon continents," and together with the oceans they create, they play a key role in the evolution of the Earth's crust.

Our team has tracked the formation of an extinct but important body of water, the Rheic Ocean, which came into being about 500 million years ago. The Rheic Ocean formed when two ancient ribbon continents, Avalonia and Carolinia, broke off the northern margin of Gondwana-an ancient, massive continent that included present-day Africa, South America, India, Australia and Antarctica. The continental collision that marked the end of the Rheic Ocean, some 350 million to 300 million years ago, was a seminal event in the assembly of Pangea.

Although geologists know which land masses surrounded the Rheic Ocean and have an approximate timeline for its birth and death, until recently we haven't been able to identify the Rheic Ocean's margins; or the causes,

J. Brendan Murphy is from Ireland. Since 1982, he has been a professor at St. Francis Xavier University in Nova Scotia, Canada, where he has taught courses in structural geology, tectonics and petrology. Gabriel Gutiérrez-Alonso is from Spain and is a professor of structural geology and global dynamics at Universidad de Salamanca. R. Damian Nance is from the United Kingdom and has been a professor at Ohio University in Athens, Ohio, since 1980. Javier Fernández-Suárez is from Spain and has been a professor of geochemistry at the Universidad Complutense de Madrid since 1998. J. Duncan Keppie is from Scotland and has 40 years' experience working in universities and geological surveys in the United States, Zambia, Canada and Mexico. At present he is at the Universidad Nacional Autónoma de México, in Mexico City. Cecilio Quesada is from Spain and has been a researcher at the Instituto Geologico y Minero de España since 1976; he specializes in the tectonic evolution of Iberia. Rob A. Strachan is from the U.K. and is at the University of Portsmouth. Jaroslav Dostal is from the Czech Republic and has taught geochemistry and petrology courses at Saint Mary's University in Nova Scotia, Canada, since 1975; he is currently a professor emeritus. Address for Murphy: Department of Earth Sciences, St. Francis Xavier University, Antigonish, Nova Scotia, B2G 2W5 Canada. Internet: bmurphy@stfx.ca mechanisms and timing of its initial opening; or why these forces reversed themselves after a few hundred million years and closed up the rift again. These questions are fundamental to geology.

Our work shows that the splitting of Avalonia and Carolinia from Gondwana happened along a line of weakened crust left over from a previous cycle of mountain building that took place some 650 million years ago. This finding is important because it suggests that pre-existing weak areas at the edges of a continent control the creation and movement of ribbon continents, thereby influencing where new oceans will form. If we're right, then our modern geography may reflect a web of ancient weaknesses that formed during successively earlier phases of plate-tectonic activity.

\section{The Geology of the Rheic Ocean}

The landmass collision that closed the Rheic Ocean was the culmination of a long period of mountain building on the northern margin of Gondwana. These forces created the Appalachian Mountains of eastern North America, the Variscan mountain belt of Europe (fragments of which are scattered from Britain to Turkey), the Anti-Atlas mountains in northwestern Africa (Morocco) and the ancestral northern Andes (Venezuela and Columbia). As they formed, these mountains encoded a record of the evolution of the Rheic Ocean. However, the formation and breakup of Pangea dispersed these terranes, or chunks of the Earth's crust, over a wide area. Much important evidence has been destroyed. For example, almost all of the rock that once formed the seafloor of the Rheic Ocean has been subducted, meaning that it has slid beneath a neighboring plate, where it sometimes melts within the Earth's viscous mantle. Studying the geology of the Rheic Ocean, therefore, is like doing a sudoku puzzle with too many empty squares. However, the work of many geologists over the past 40 years has identified some key sites that allow the story of the Rheic Ocean to be told.

The fundamental weaknesses that determined the location of the Rheic Ocean were created by even older plate tectonic events. Thus, to understand the forces that influenced Rheic Ocean formation we need to go back to between 650 million and 500 million years ago, when the Amazonian and African margins of Gondwana (the northern edge in present coordinates) underwent a complex evolution.
About the time that Gondwana formed, between 600 million and 550 million years ago, most geologists believe a large landmass to the north broke up, creating the continents of Laurentia (ancestral North America), Amazonia (northern South America) and Baltica (mainly Scandinavia). The Iapetus Ocean formed in the space between these drifting continents and Gondwana. (In Greek mythology, Iapetus was the father of Atlas, after whom the Atlantic Ocean is named.)

The evolution of the northern margin of Gondwana was analogous to that of North America's Rocky Mountains and South America's Andes. The geology of these three sites (two modern and one archaic) involved the subduction and separation of continental blocks (such as Baja California), which in turn produced large quantities of magma, or molten rock. The chemical makeup of igneous rocks (which are made of cooled magma) produced at the Gondwanan margin is very similar to that of igneous rocks in the Andes-both are characteristic of the magma created above a subduction zone.

Although fragments of this margin now occur as terranes in younger orogenic belts (which refer to a range of mountains or their remnants), the former association of these fragments with Gondwana is generally accepted because of similarities in the rock and fossil records. Studies that examine the orientation of magnetic minerals in the rocks also indicate that these terranes formed at the same latitude as the northern Gondwanan margin. The remains of these ancient volcanoes and magma chambers, now exposed as a result of uplift and erosion of the crust, show that this magmatism ended between 600 and 540 million years ago, probably because of the development of a fault system associated with the collision of an ocean ridge with a subduction zone. This scenario is analogous to the collision, some 30 million years ago, between the $\mathrm{Pa}$ cific Ocean ridge and a subduction zone along the West Coast of North America, which gave rise to the San Andreas Fault and shut down subduction-related magmatism in the southwestern United States and northwestern Mexico. Along the northern Gondwanan margin, some terranes were shuffled sideways considerable distances (possibly up to 1,000 kilometers) during this period, a phenomenon that also has parallels with western North America. 
Between 540 million and 500 million years ago, subduction-style and San Andreas-style plate tectonics gave way, leaving a relatively stable continental platform environment dominated by sedimentary rocks. This time interval coincided with the worldwide appearance of shelly fossils, so strata of this age are rich with the remains of these animals.

In each of these terranes, the rock record between 650 million and 500 million years ago demonstrates that the terranes faced an open ocean during this entire interval, even though the plate-tectonic setting changed. However, the geological similarities ended about 500 million years ago, heralding the development of the Rheic Ocean. Some terranes, such as those in Iberia and the Oaxacan region of southern Mexico, show deepening sedimentation between 500 million and 440 million years ago. Other terranes, such as Carolinia and Avalonia in the Appalachians, have thin sediment strata from this period, indicating greater distance from a large source of sediment (such as Gondwana). This change marks the opening of the Rheic Ocean (named after Rhea, the sister of Iapetus in Greek mythology). In addition, the fossils of Carolinia and Avalonia become increasingly distinct from those of Gondwana.

By 460 million years ago, magnetic signatures in the rock show that Avalonia was about 1,700-2,000 kilometers north of the Gondwanan margin, implying that the Rheic Ocean widened at a rate of 6 to 8 centimeters per year. At that time, Avalonia and Carolinia were New Zealand-like ribbon continents separating the Iapetus Ocean to the north from the Rheic Ocean to the south. However, as Avalonia and Carolinia cruised north, the northern margin of Gondwana remained at a latitude of about 60 degrees South and the southern margin of Laurentia lay at about 10 degrees South. Hence, widening of the Rheic Ocean behind these terranes was more or less compensated by closure of the Iapetus Ocean ahead of them.

By 440 million years ago, magnetic data show that Avalonia was close to Baltica (western Europe) and eastern Laurentia. Over the next 30 million years, these continents converged to form a larger continent, Laurussia. This amalgamation effectively closed the Iapetus Ocean. As the Rheic Ocean was gradually subducted beneath Gondwana, Laurussia was pulled south. The two continents collided to form Pangea between 320 and 290 million years ago.
Although this account answers many questions about this process, it does not address why the Rheic Ocean formed where it did in the first place. To answer that question, we now focus on the mechanisms by which Avalonia and Carolinia separated from Gondwana some 485 million years ago.

The Formation of Crustal Weaknesses Terranes play a key role in mountain building as they collide with continental margins. The most celebrated example of this process is found along the western margin of North America, where the sequential collision of terranes has resulted in pulses of mountain-building activity that helped form the Rocky Mountains.

Our work indicates that the site of the Rheic Ocean's formation was dictated by geologic events that took place about 150 million years earlier. These events formed fundamental zones of weakness along the northern Gondwanan margin that became unhealed wounds in the crust. But how did these weak zones form?

Our data show that despite their broadly similar rock types, 630-million to 570-million-year-old igneous rocks that formed along the northern Gondwanan margin can be divided into two groups based on age and composition of their source material. One group is characterized by magmas that came from the melting of an older continental "basement" - the foundation on which sedimentary rock rests. The other group is characterized by magmas derived from a younger underlying basement.

These terms, "older" and "younger," are relative- the young group is about a billion years old. Geologists can deduce the age of the basement that melted to form the igneous rock by measuring the ratio of samarium $(\mathrm{Sm})$ and neodymium $(\mathrm{Nd})$ isotopes it contains (the sidebar on the next page explains this technique). This ratio, expressed as $\varepsilon_{\mathrm{Nd}}$, shows when the rock first formed from the bulk of the Earth's mantle. Even if the rock later melts, it retains that characteristic isotope ratio until it is absorbed back into the mantle.

The first, more ancient group of igneous rocks from Gondwana can be found today in northwestern France, southern Iberia and parts of Germany. These rocks have predominantly negative $\varepsilon_{\mathrm{Nd}}$ values (typically between +1.6 and -9.9), which indicate that even though the rocks formed from cooled

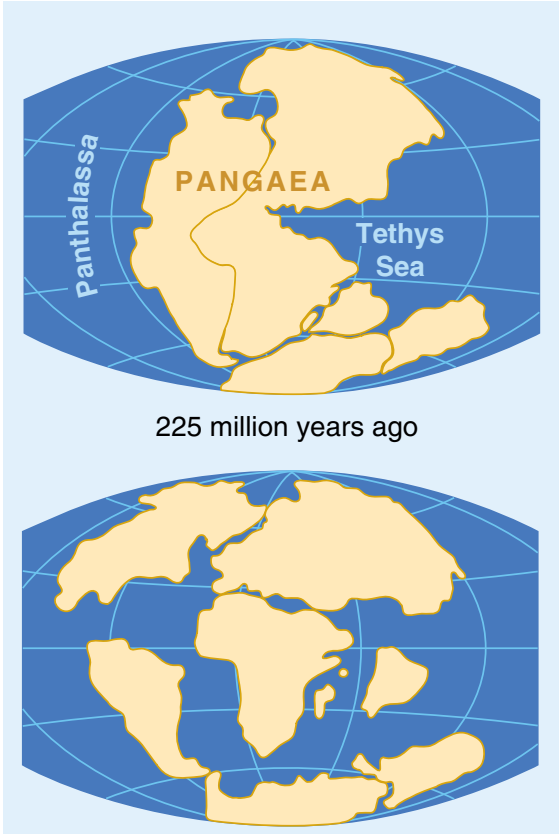

65 million years ago

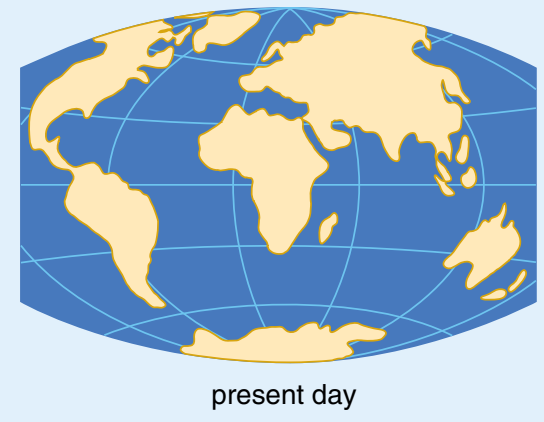

Figure 2. The breakup of Pangea, which began about 200 million years ago, created the Atlantic Ocean between the Americas and what are now Europe and Africa. At the same time, the Tethys Sea, which once existed between India and Asia and between Africa and Europe, closed as those pairs of continents collided. During this period, the worldspanning ocean Panthalassia was reduced to the Pacific Ocean, which continues to shrink through subduction around its perimeter.

magma about 600 million years ago, the magma itself came from the melted remains of a continent that was between 1.0 billion and 2.0 billion years old.

Parts of this ancient continental basement are actually exposed in northwestern France. Scott Samson of Syracuse University and Richard D'Lemos of Oxford Brookes University determined that this basement is about 2.1 billion years old. Hence, the most likely explanation for the $\mathrm{Sm}-\mathrm{Nd}$ data is that they reflect melting of a crustal source about 2.1 billion years old that mixed with younger, or "juvenile," magmas from the mantle during rock 
formation. Samson and D'Lemos's calculation is very similar to that for an ancient basement exposed in West Africa. In almost all reconstructions of the geography of this time period, the West African basement is placed along the northern Gondwanan margin. Hence, the older group of igneous rocks from the northern margin of Gondwana was probably composed of melted West African basement.

The second group of rocks is found in eastern Canada and the United States; southern Britain; central and northern Iberia; and portions of eastern Germany, the Czech Republic and Poland. These igneous rocks are characterized by predominantly positive $\varepsilon_{\mathrm{Nd}}$ values that range between +5.0 and -1.0 . These values correspond to an age range between 750 million and 1.1 billion years. There is very little overlap with the first group. This means that, despite outward similarities, the 630-million to 570million-year-old igneous rocks from the northern margin of Gondwana were derived from fundamentally different sources. Those from the first group were made of magma from ancient rock, possibly 2.1 billion years old, whereas those from the second group were made from magma that came more recently from the Earth's mantle, between 1.1 billion and 750 million years ago.

We and our colleagues have found other evidence that supports these observations. In sedimentary rocks interbedded with the igneous layers, we found fragments of eroded bedrock that had settled into ancient drainage basins. Some of the minerals in the bedrock, notably zircon and white mica, can be dated by measuring the decay of uranium, potassium or argon isotopes. In the first group, the minerals had calculated ages that clustered at the intervals 600 million-650 million years, 2.0 billion-2.2 billion years, and 2.4 billion-2.6 billion years. In contrast, the ages of minerals in the second group fall into categories of 1.0 billion-1.2 billion years, about 1.5 billion years, and 1.8 billion- 2.0 billion years. These data show that these two groups of sedimentary rocks were attached to different continental drainage systems at the time of their formation. Furthermore, the zircon ages from the first group of rocks match those of the potential source basement in West Africa, thereby supporting a West African connection.

But if the first group of igneous rocks is made from the ancient West

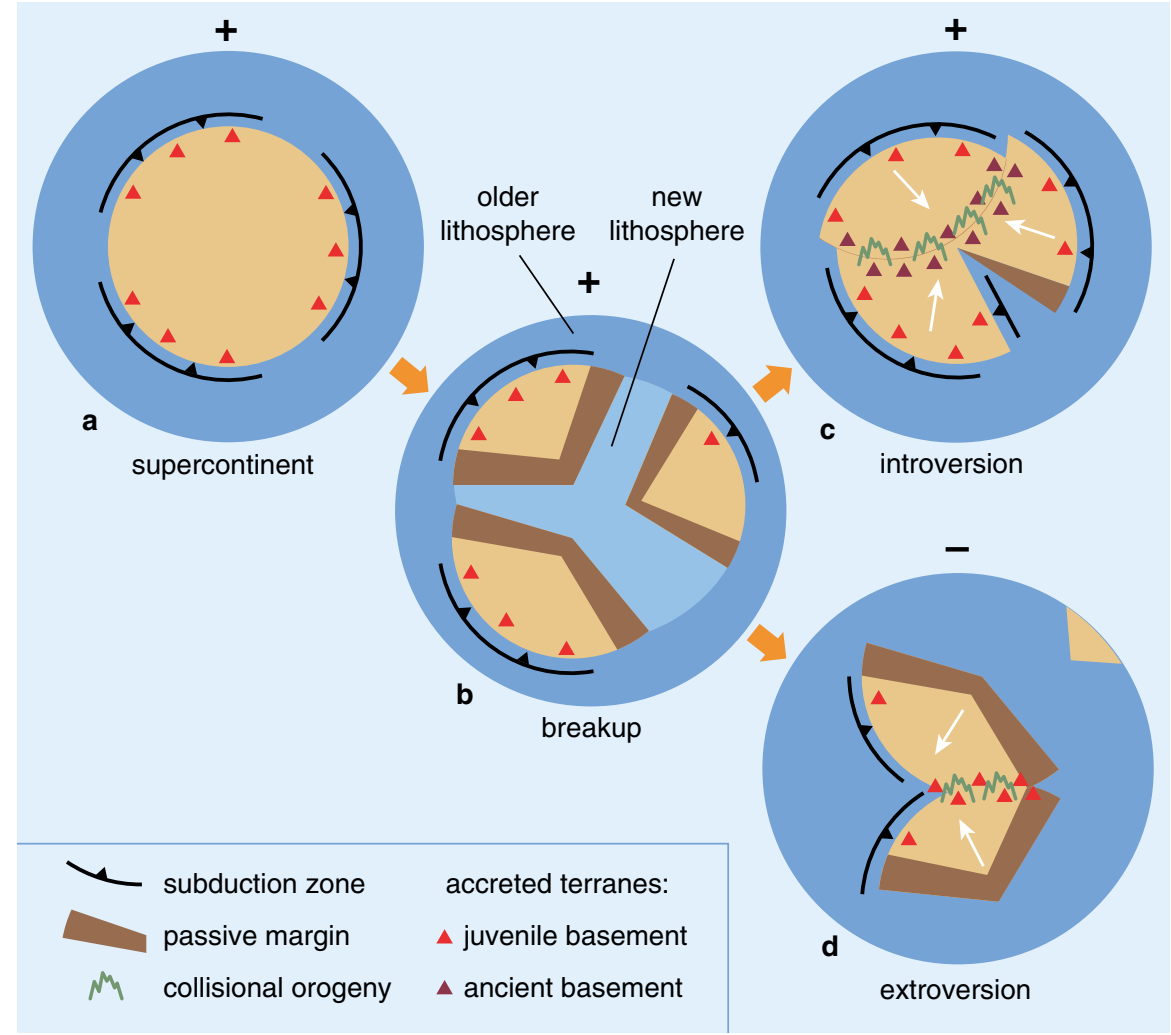

Figure 3. Supercontinents are surrounded by an "exterior" ocean and have subduction zones and volcanic regions around their margins $(a)$. The breakup of a supercontinent creates a new, "interior" ocean between the dispersing landmasses $(b)$. The geological record shows that either the interior $(c)$ or exterior $(d)$ ocean can close to form the next supercontinent. Triangles indicate accreted terranes made of juvenile basement (red) or ancient basement (purple).

African basement, what is the source for the second group of rocks? A clue to this mystery came from the specific age of the rock-between 750 million and 1.1 billion years old, according to the Sm-Nd data. This interval corresponds to an important event in world geography. About 1.0 billion to 1.1 billion years ago, the collision of many continents led to widespread mountain building and the eventual formation of the supercontinent Rodinia, so named after the Russian word for "homeland." Furthermore, the widespread development of continental shelves and new, mantle-derived magmas about 750 million years ago is thought to reflect the breakup of this supercontinent.

Thus, the age of the magma used in creating our second group of igneous rocks coincides with the lifespan of Rodinia. However, the basement source of this group could not have been the continent of Rodinia itself, since that continental crust came from an even earlier time. Instead, the basement must have come directly from the mantle beneath the ocean that surrounded Rodinia. This ocean is called the Mirovoi Ocean (after the Russian word for "world").
Thus, our second group of terranes from the northern margin of Gondwana must have originated well offshore, rather than along the continent. Furthermore, they must have collided with the northern Gondwanan margin before the main arc event 635 million to 570 million years ago, because we know that by that time, the juvenile signature of that basement shows up in new igneous rock.

This collision of a terrane with a continental margin is known as accretion, which causes the formation of mountains that contain deformed and recrystallized, or metamorphic, rocks. For the second group, records of metamorphic events in southern Britain and parts of eastern North America (southern Newfoundland, Maine and Carolina) are consistent with accretion of these terranes between 680 million and 650 million years ago. The first group, however, bears no evidence of accretion. As before, this observation suggests that these terranes lay along the West African margin of Gondwana and so reflect the in situ recycling of West African crust.

The contrast between the terranes that lay along the Gondwanan margin 


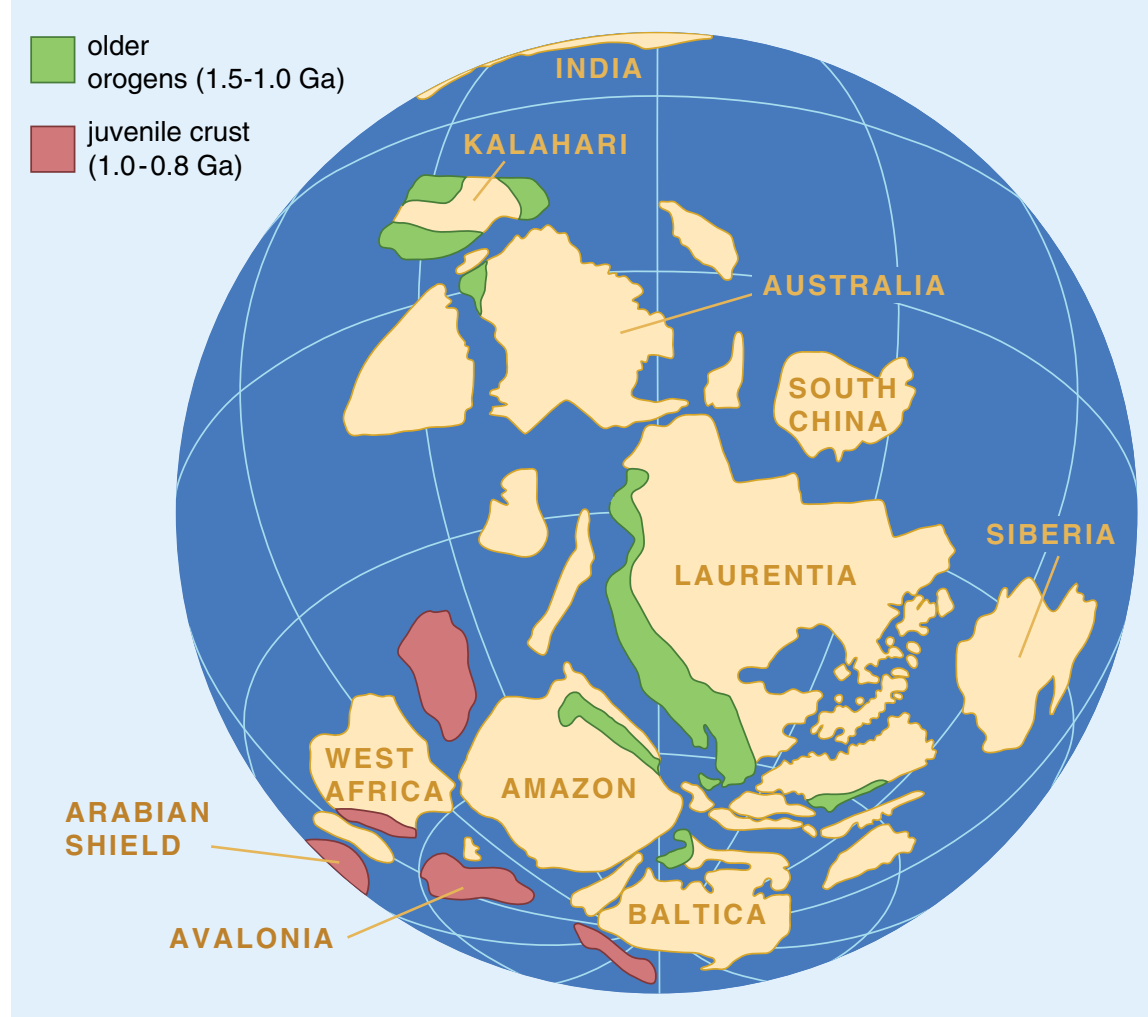

Figure 4. The supercontinent of Rodinia began to break up roughly 800 million years ago. Ranges of ancient mountains are shown in green. Red areas show the inferred location of the juvenile crust, some of which later formed Avalonia and Carolinia. The location of this crust is not known with any certainty, but for illustration purposes, it is positioned outboard of the older cratons (stable continental masses) onto which it had accreted by about 550 million years ago. (Based on data from Sergei Pisarevsky, University of Edinburgh.)

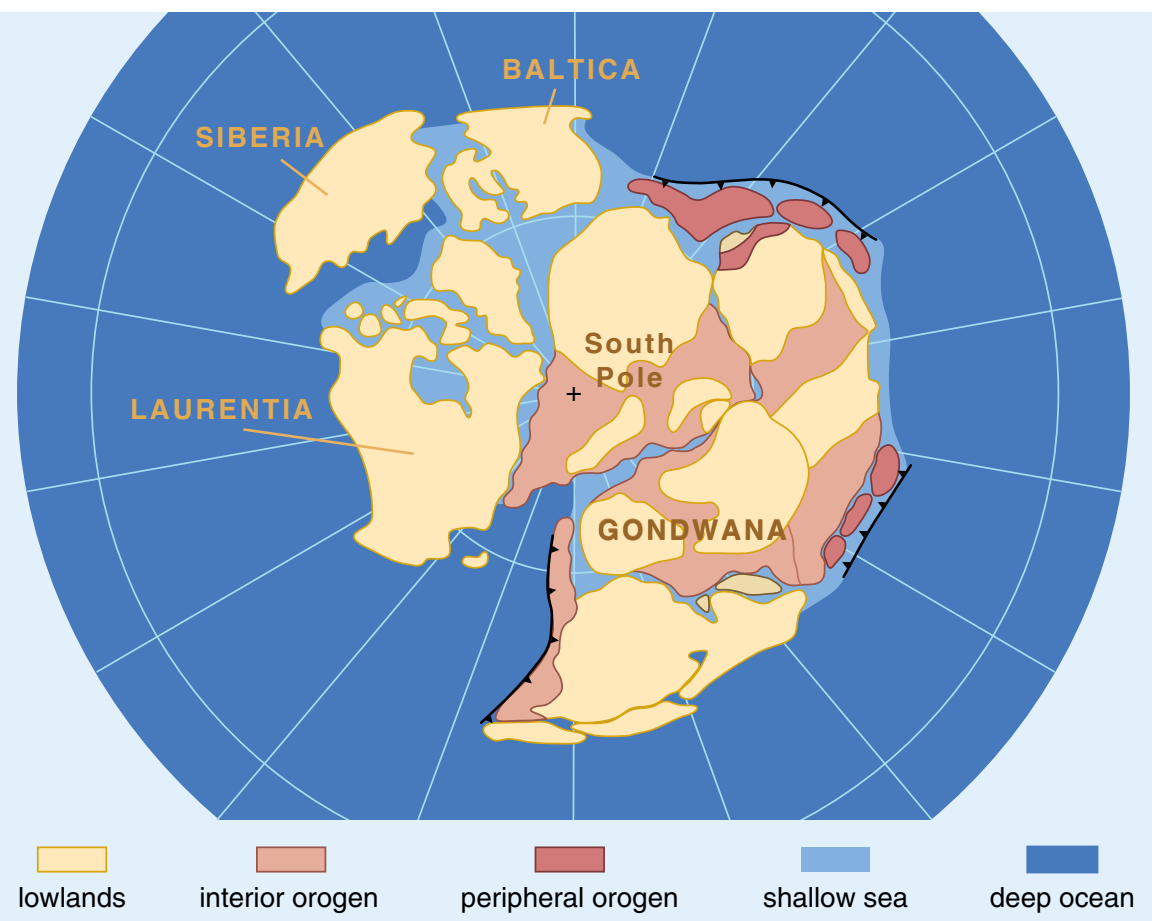

Figure 5. Between 650 million and 550 million years ago, the Iapetus Ocean began to form between Gondwana and Laurentia. Interior orogens are mountain ranges created by the collision of tectonic plates. Peripheral orogens are formed by subduction and accretion around the edges of a supercontinent. Black lines mark the edges of subduction zones on the outer margins of Gondwana. and those that were accreted to this margin means that a fundamental divide, or suture, must have existed between them. Western North America carries a modern example of such a suture. Over the past 150 million years, several terranes that once lay within the Pacific Ocean were swept towards and accreted to continental North America, resulting in several pulses of mountain building. As a result, a fundamental suture exists between these accreted terranes and the more ancient continent in North America and in Gondwana.

\section{The Origin of the Rheic Ocean}

It is now clear that the Rheic Ocean was formed by the rifting and separation of the very terranes (Avalonia and Carolinia) that had accreted to the Gondwanan margin 160 million years earlier. Both ribbon continents were, of course, oceanward of the suture with the main continent. With few exceptions, those terranes lying landward of the suture remained attached to Gondwana, according to fossil evidence and magnetic data.

The first rifting event took place between 540 million and 490 million years ago, after the quieting of subductionrelated igneous activity. The rifting was followed by widespread accumulation of deposits from the continental margin and local volcanic activity. It's possible that Avalonia and Carolinia separated from northern Gondwana by sideways movement along the suture- the modern Gulf of California opened as a result of similar forces, which have caused a northward migration of the Baja Peninsula along the San Andreas Fault. The fossil content and magnetic data from this period suggest that, like the Gulf of California, the Gondwanan seaways were narrow.

A second rifting event began about 490 million years ago, when Avalonia and Carolinia began to drift across the Iapetus Ocean. The increasing separation from Gondwana can be seen in the different fossil assemblages from this period.

By 460 million years ago, Avalonia lay at a latitude of about 40 degrees South, or about 1,700-2,000 kilometers south of Laurentia, whereas northern Gondwana remained at 60 degrees South. These data imply a northward drift for Avalonia of 6 to 8 centimeters per year. Carolinia lay further north and may not have been connected to Avalonia at that time. But their separation from both Laurentia and Gondwana suggests that they 
ca. $540 \mathrm{Ma}$

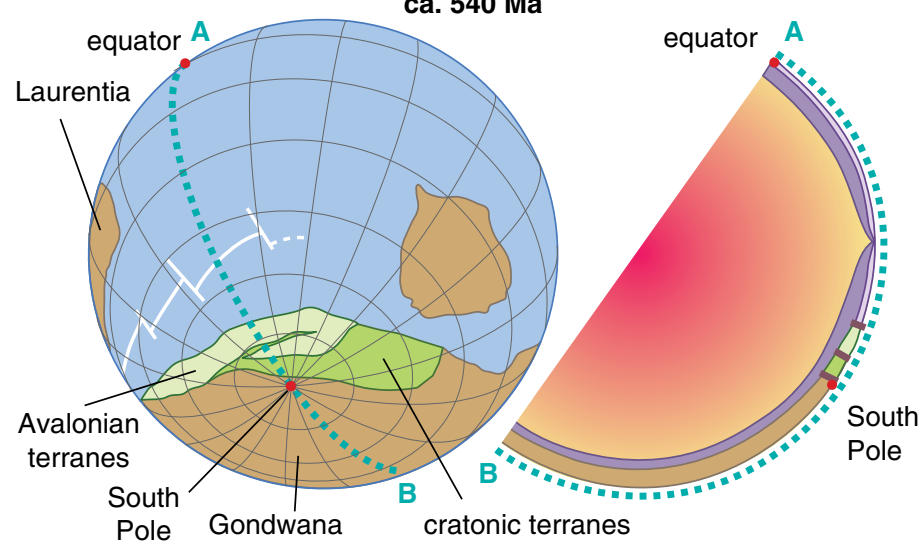

ca. $480 \mathrm{Ma}$

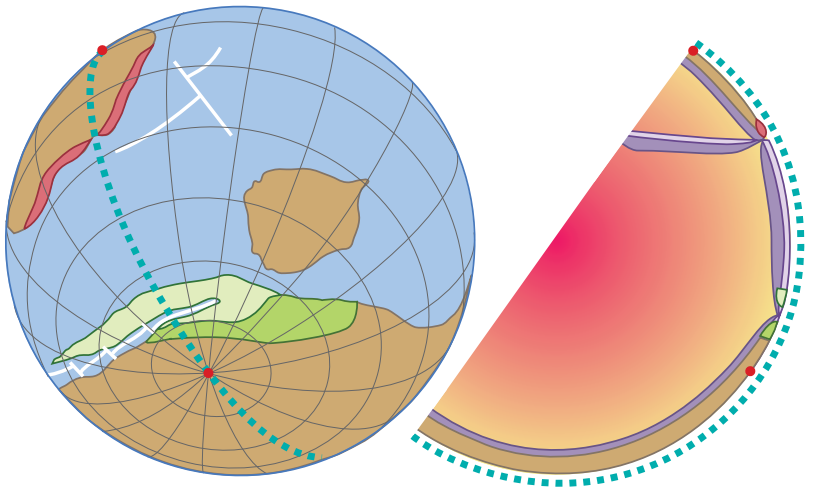

ca. $450 \mathrm{Ma}$

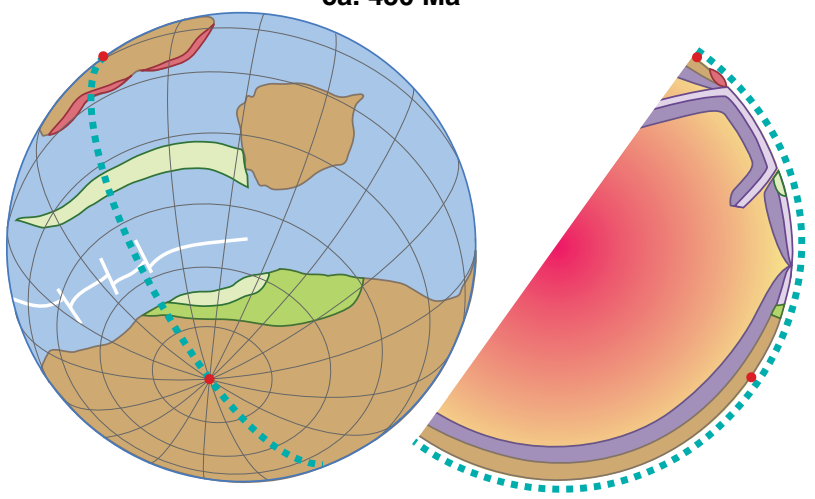

lapetus and Rheic oceans

cratons
Avalonian basement

Cadomian basement

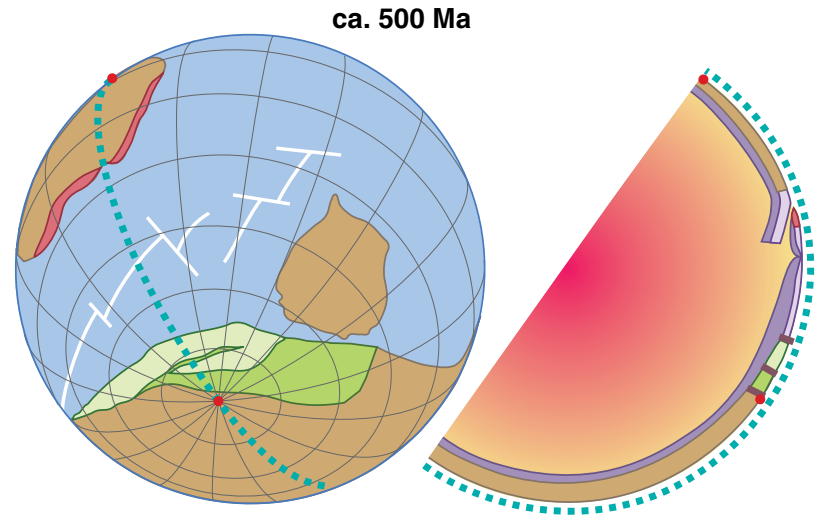

ca. $470 \mathrm{Ma}$

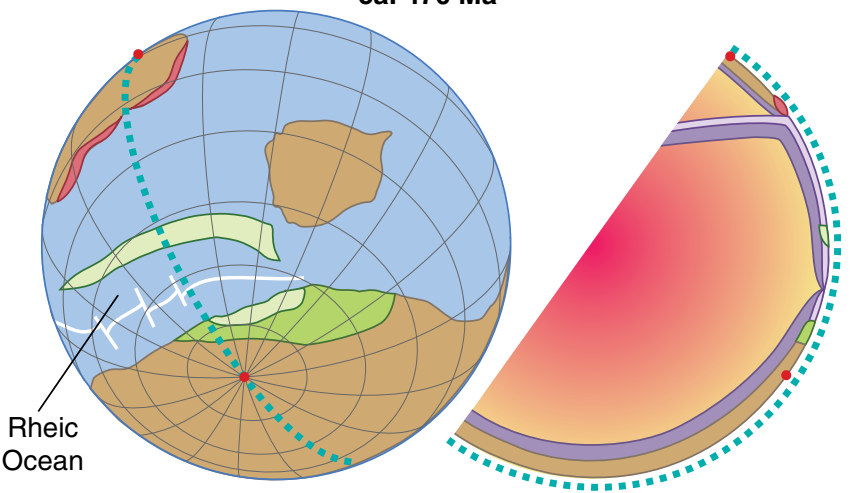

ca. $430 \mathrm{Ma}$

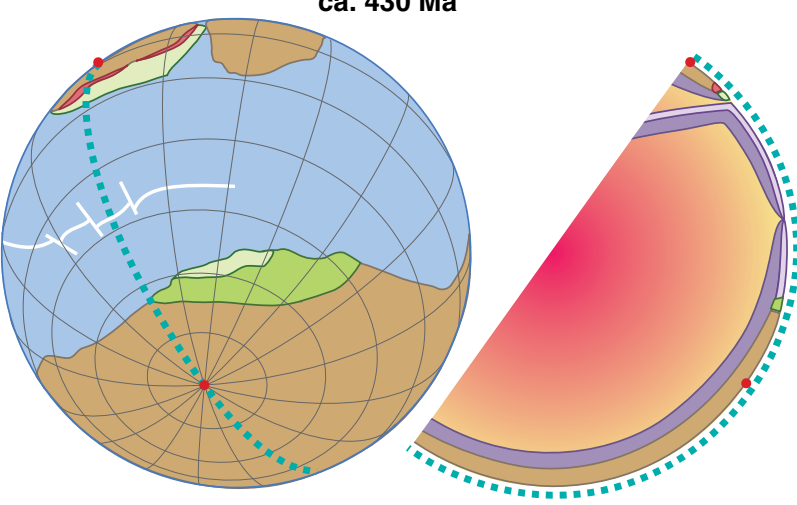

lithospheric mantle

core and mantle

(except lithospheric)

oceanic crust

Taconic volcanic arc

Figure 6. This series of global reconstructions and cross-sections depicts the forces that created the Rheic Ocean and determined its evolution over a period from 540 million to 430 million years ago. By 540 million years ago, the Iapetus Ocean stretched from Laurentia to Gondwana, with a midoceanic ridge (white) in between. Younger Avalonian terranes (light green) moved northward, grinding against the older cratonic terranes (green) along the northern margin of Gondwana. By 500 million years ago, southward-directed subduction started to close the northern flank of the Iapetus Ocean, forming arcs of volcanos (red). As outlined by Cees van Staal, Geological Survey of Canada, by 480 million years ago, Laurentia collided with those arcs, and the direction of subduction reversed, leading to subduction of the ridge in the Iapetus Ocean. After that time, the oceanic crust beneath Laurentia and along the margin of Gondwana were at different ends of the same plate. Slab pull caused by subduction beneath Laurentia may have ripped apart the Avalonian-Cadomian suture at the other end of the plate, forming the Rheic Ocean as Avalonia drifted away from Gondwana. Between 470 and 450 million years ago, subduction beneath the northern Avalonian margin formed another set of volcanic arcs. By 430 million years ago, Avalonia had accreted to Baltica and then Laurentia, thereby closing the Iapetus Ocean. Note the positions of the south pole and the equator; for clarity, cross-sections are not drawn to scale. 


\section{Isotopic Tracing}

$\mathrm{T}$ racking the geological heritage of a terrane is similar to tracking the heritage of a family name. Many families in North America, for example, can trace their heritage back to Scotland. Over the centuries, some traits have been lost (such as Scottish accents), but others, including surnames and traditional music and dance, have been handed down from generation to generation. Similarly, the passage of time has obliterated many traits from rocks, but others are unaffected. Isotopes of the rare-earth elements samarium (Sm) and neodymium $(\mathrm{Nd})$ are examples of the latter. The ratio of these isotopes can identify the time at which a rock first formed from the mantle.

Isotopes are atoms of the same element that differ slightly in mass. Many elements have several isotopes, some of which are unstable, or radioactive. Such isotopes spontaneously decay to a more stable form, giving off energy in the process. The time it takes for half of an unstable "parent element" to decay to its stable "daughter element" is known as the half-life and is constant. The half-life and the parent-daughter ratio can be measured and used to calculate the length of time over which decay has occurred. For volcanic rocks, this is typically the crystallization age of the rock sample.

The pioneering work of several geoscientists, notably Don DePaolo of the University of California at Berkeley, has shown that the decay of Sm to Nd is one of the best tracers of tectonic and igneous processes. These two elements have similar chemical properties, but in places where the mantle begins to melt, Nd (the lighter of the two) becomes slightly more concentrated in liquid magma leaving the mantle. Accordingly, Sm becomes slightly more concentrated in the remaining mantle, which is said to be depleted.

The average $\mathrm{Sm} / \mathrm{Nd}$ ratio for the Earth as a whole is about 0.32. But because of the tendency for $\mathrm{Nd}$ to concentrate in liquids bound for the crust and for $\mathrm{Sm}$ to concentrate in the depleted mantle, the ratio of $\mathrm{Sm} / \mathrm{Nd}$ in crustal rocks is lower (about 0.2), and the ratio in the depleted mantle higher (about 0.5) than that of the bulk Earth.

Samarium-147 $\left({ }^{147} \mathrm{Sm}\right)$ is a radioactive isotope that decays to form neodymium-143 $\left({ }^{143} \mathrm{Nd}\right)$, which is stable. Thus, the amount of ${ }^{143} \mathrm{Nd}$ steadily in- creases as ${ }^{147} \mathrm{Sm}$ decreases. The half-life for this decay is 106 billion years.

Neodymium-144 is also stable but isn't produced by radioactive decay, so the levels of this isotope in a given rock do not change with time. Because ${ }^{143} \mathrm{Nd}$ increases over geologic time and ${ }^{144} \mathrm{Nd}$ stays the same, the ratio of ${ }^{143} \mathrm{Nd}$ to ${ }^{144} \mathrm{Nd}$ has also increased in crustal rocks, the depleted mantle and the bulk Earth. But because Sm/Nd is higher in the depleted mantle than it is in the bulk Earth, and higher in the bulk Earth than it is in the crust, the decay of ${ }^{147} \mathrm{Sm}$ to ${ }^{143} \mathrm{Nd}$ causes the ${ }^{143} \mathrm{Nd} /{ }^{144} \mathrm{Nd}$ ratio to increase more rapidly in the depleted mantle than in the bulk Earth, and more rapidly in the bulk Earth than in the crust. As a result, the Sm-Nd isotopic characteristics of magmas generated in the depleted mantle are very different from those generated in the crust.

Magmas retain the ${ }^{143} \mathrm{Nd} /{ }^{144} \mathrm{Nd}$ ratio of their source, so magmas made of melted mantle will have higher ${ }^{143} \mathrm{Nd} /{ }^{144} \mathrm{Nd}$ ratios than those made of melted crust. If geologists know the time at which that magma crystallized, they can correct for the amount of radioactive decay and deduce the ${ }^{143} \mathrm{Nd} /{ }^{144} \mathrm{Nd}$ ratio in the original magma. This so-called initial ratio, $\left({ }^{143} \mathrm{Nd} /{ }^{144} \mathrm{Nd}\right)_{0}$, is the fingerprint that determines where the melt originated. In this way, volcanic rocks recently derived from the mantle can be distinguished from those derived from the recycling of ancient crust, or those that represent mixtures of both.

In absolute terms, the differences in the ${ }^{143} \mathrm{Nd} /{ }^{144} \mathrm{Nd}$ ratios of crustal and mantle rocks are small. For convenience, therefore, geologists define a parameter, $\varepsilon_{\mathrm{Nd}}$, which reflects the difference between the initial ${ }^{143} \mathrm{Nd}$ / ${ }^{144} \mathrm{Nd}$ ratio in the sample and that of the bulk Earth at the time the rock crystallized. In this scheme, $\varepsilon_{\mathrm{Nd}}$ for the bulk Earth at any time is given a value equal to zero. Since ${ }^{143} \mathrm{Nd} /{ }^{144} \mathrm{Nd}$ increases more rapidly in the depleted mantle and less rapidly in the crust than it does in the bulk Earth, the values of $\boldsymbol{\varepsilon}_{\mathrm{Nd}}$ have over time grown more positive for the depleted mantle and more negative for the crust. This evolution is known as a growth line.

In practical terms, the geologist uses these principles in reverse. For crustally derived rocks, a sample's
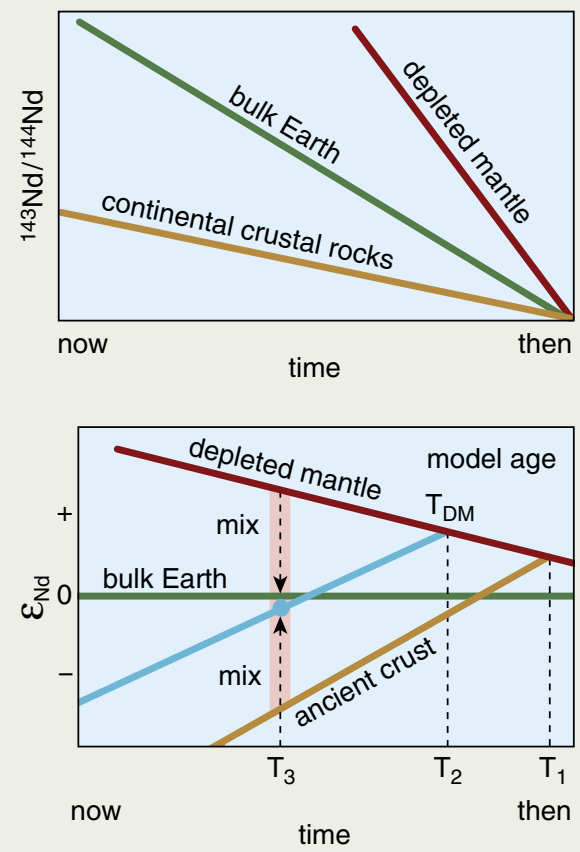

The depleted mantle retains more samarium $(\mathrm{Sm})$ relative to neodymium $(\mathrm{Nd})$ than the liquid magma that becomes continental crust. Thus, the depleted mantle has a ratio of $\mathrm{Sm} / \mathrm{Nd}(\sim 0.5)$ that is greater than that of bulk Earth ( 0.32) or continental crust ( 0.2). These ratios, plus the steady, radioactive decay of ${ }^{147} \mathrm{Sm}$ to ${ }^{143} \mathrm{Nd}$, mean that the initial ratio of ${ }^{143} \mathrm{Nd} /{ }^{144} \mathrm{Nd}$ increases more rapidly in the depleted mantle than it does in bulk Earth and continental crust (top). The differences in initial ratios between depleted mantle or crust and bulk Earth (which is fixed at zero) are expressed as $\varepsilon_{\mathrm{Nd}}$. With the $\mathrm{Sm} / \mathrm{Nd}$ ratio and the $\varepsilon_{\mathrm{Nd}}$ value for a sample (calculated from the time it crystallized), geologists can determine a growth line (bottom, blue line) that projects back in time and intersects the depleted mantle line. This intersection indicates the depleted mantle $\left(\mathrm{T}_{\mathrm{DM}}\right)$ "model" age- the time at which the crust was derived from the mantle $\left(T_{2}\right)$. Mixing of juvenile magma with ancient crust $\left(T_{1}\right)$ can yield spurious results $\left(T_{3}\right)$.

growth line (its change in $\varepsilon_{\mathrm{Nd}}$ with time) can be calculated and extrapolated backwards in time until it intercepts the depleted-mantle growth line. This is the time when the sample had the same isotopic signature as its depleted-mantle source-in other words, the time when that crust was first extracted from the mantle. Such calculations must be used with caution: As magmas ascend to the surface, they may mix with other melts from different sources, and mixed samples yield unreliable data. However, geologists can usually detect the telltale signs of mixing using other indicators, so contaminated samples can be excluded. 
Avalonian type

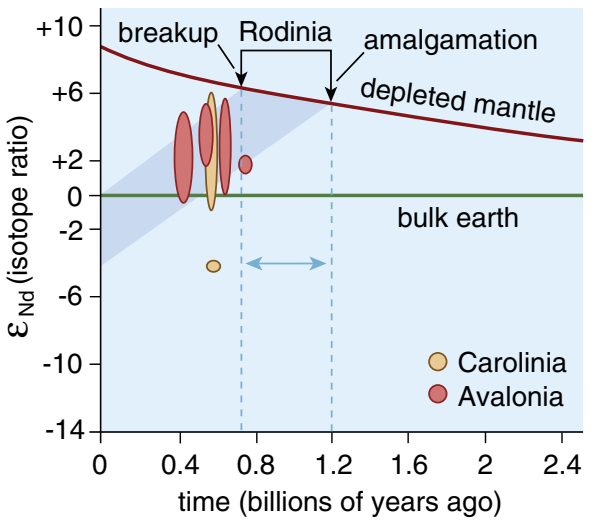

cratonic type

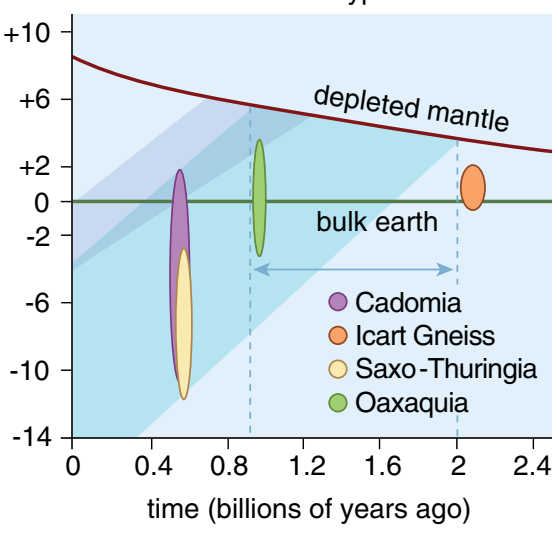

Figure 7. The ratio of neodymium isotopes $\left(\varepsilon_{\mathrm{Nd}}\right)$ in rock can indicate the time at which it first emerged from the Earth's mantle. This signature is fixed until the rock rejoins the mantle-even if the rock is melted and recycled. When the authors examined igneous rocks from the northern margin of Gondwana, they found that the samples clustered into two distinct age groups, as shown in these plots of $\varepsilon_{\mathrm{Nd}}$ vs. time (in billions of years ago). Thus, the accreted (younger) terranes (left) were made of the melted remains of younger crust, which first formed from the depleted mantle between 750 million and 1.1 billion years ago. In contrast, the cratonic (older) terranes (right) were composed of the melted remains of much older crust that issued from the mantle between 1.5 billion and 2.1 billion years ago. The accreted terranes shown here include Avalonia (which now makes up eastern North America and southern Britain) and Carolinia (part of the eastern United States). The cratonic terranes include Cadomia and Icart Gneiss (found in northwest France), Saxo-Thuringia (portions of Germany) and Oaxaquia (Mexico). Note that the field for accreted terranes coincides with the lifespan of the supercontinent Rodinia; arrows indicate the times of its amalgamation and breakup. The field for cratonic terranes is older and broader.

were New Zealand-like islands whose northward drift progressively closed the Iapetus Ocean while the Rheic Ocean opened behind them.

Taken together, these data suggest that the sites of initial rifting and subsequent opening of the Rheic Ocean were profoundly influenced by reactivation of the suture zones generated some 650 million years ago by the accretion of juvenile terranes to the Gondwanan margin. Extension stresses must have reactivated this old wound, resulting in the separation of terranes on its oceanward side.

But what caused this extension? The actual mechanism that explains the splitting off and release of a terrane (so called rift-to-drift) is uncertain, and several models have been proposed. Terranes can be separated from the margins of continents during subduction if the subducting slab rolls backward as it descends into the mantle. Such processes have been documented in the modern western Pacific Ocean. However, terranes that are separated in this fashion remain geologically linked to the continental margin; many eventually re-accrete. With Avalonia and Carolinia, evidence of igneous rocks formed by this type of process is equivocal.

A more likely mechanism for the opening of the Rheic Ocean is suggest- ed by the timing of the most important phase of rifting, which began 490 million years ago. In the Iapetus Ocean at that time, accretion of oceanic terranes and collision with an oceanic ridge caused a deformation along the Laurentian margin. Following this, a new phase of subduction began beneath the Laurentian margin. After the ridge collided, the new subduction zone would have been connected to the northern margins of Avalonia and Carolinia. As subducting slabs undergo mineralogical changes that make them denser, they exert a force known as slab pull-much the same way that a heavy tablecloth draped too far over the edge will slide off, carrying the crockery with it. Avalonia and Carolinia may have been pulled away from Gondwana by slab pull associated with subduction beneath the Laurentian margin.

\section{Setting the Stage for Pangea}

The agglomeration of continents that destroyed the Rheic Ocean culminated in the collision of Gondwana with Laurussia, a pivotal event in the formation of Pangea. Understanding the origin and evolution of this extinct body of water is, therefore, fundamental to understanding the forces that created Pangea. The Rheic Ocean opened with the departure of a narrow continent from the northern margin of Gondwana. By using isotopic tracing techniques, we can show that this microcontinent originated within the Mirovoi Ocean between 750 million and 1.0 billion years ago, and that it was accreted to Gondwana about 650 million years ago. A fundamental zone of weakness, or suture, separated the newly accreted terrane from the ancient Gondwanan margin. Subduction beneath this margin, which started about 635 million years ago and lasted up to 90 million years in some places, created widespread magmatism in the accreted terranes and in the ancient (West African) crust of Gondwana.

Between 540 million and 500 million years ago, a platformal environment became established. About 490 million years ago, those terranes that had previously accreted to the Gondwanan margin (Avalonia and Carolinia) began to separate from that margin and, by 460 million years ago, had migrated about 2,000 kilometers north. We believe that these terranes were pulled away from Gondwana because the pulling force of the slab as it subducted beneath the Laurentian margin tore open the ancient suture. In this way, the site of the Rheic Ocean may have been inherited from a fundamental weakness in the crust that was made by previous collisions.

\section{Bibliography}

Arndt, N. T., and S. L. Goldstein. 1987. Use and abuse of crust formation ages. Geology 15:893-895.

Murphy, J. B., G. Gutiérrez-Alonso, R. D. Nance, J. Fernández-Suárez, J. D. Keppie, C. Quesada, R. A. Strachan and J. Dostal. 2006. Origin of the Rheic Ocean: rifting along a Neoproterozoic suture? Geology 34:325-328

Murphy, J. B., and R. D. Nance. 2004. How Do Supercontinents Form? American Scientist 92:324-333.

Pisarevsky, S. A., M. T. D. Wingate, C. M. Powell, S. Johnson and D. A. D. Evans. 2003. Models of Rodinia assembly and fragmentation. In Proterozoic East Gondwana: Supercontinent Assembly and Breakup, ed. M. Yoshida, B. Windley and S. Dasgupta, 35-55. The Geological Society, Special Publication 206. London.

For relevant Web links, consult this issue of American Scientist Online:

http://www.americanscientist.org/ IssueTOC/issue/1061 